Universal Decimal Classification (UDC) 614.5:644.36

\title{
BLUE LED LIGHT AS A NEW HYGIENIC PROBLEM
}

\author{
Kaptsov V.A. ${ }^{1}$, Deinego V.N. ${ }^{2}$

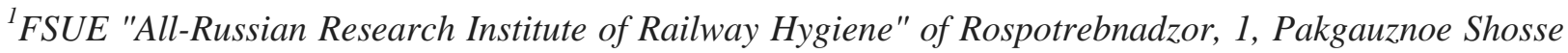 \\ st., Bldg. 1, Moscow, 125438, Russian Federation \\ ${ }^{2}$ LLC "New Energy Technologies", 100, Novaya, Odintsovsky district, Moscow region, village Skolkovo, \\ 143025, Russian Federation
}

The paper focuses on the geneeration of the excessive dose of the blue light in the LED light. It shows that the photobiological assessments made in accordance with GOST R IEC 62471-2013 need to be revised accounting for the changes in the pupil size in the LED light and the spacial distribution of the blue light absorbing pigment $(460 \mathrm{~nm})$ in the yellow spot. The paper decscribes the methodological principles of the calculation of the excessive dose of the blight light in the LED spectrum as compared to sunlight. It is noted that today in the USA and in Japan, the concept of LED lighting has changed, and white light LED have been produced to minimize the health risks. In particular, in the USA this concept includes not only the general lighting, but also the monitros and car headlights.

Keywords: LED, excess dose of blue in the spectrum of artificial white light sources, Photobiological security, national security.

Today LED lighting is prescriptively installed in schools, kidnergartends and healthcare facilities. The assessment of its photobiological safety is based on GOST R IEC 62471-2013 "Photobiological safety of lamps and lamp systems". The GOST document was prepared by the State Unitary Enterprise of the rpublic of Mordovia "Lodygin Scientific and Research Light Source University" based on own Russian translation of the document mentioned in clause 4 below. The clause indicates that the present document is identical to the international standard IEC 62471:2006 Photobiological safety of lamps and lamp systems. Such transfer of the guideline document points to the fact that Russia does not have own professional school of photobiological safety.

Photobiological safety assessment is based on the risk theory and quantitative estimate of the marginal rates of the standard influence of the blue light on retina. The marginal values of photobiological safety was calculated for the established exposure limit of the pupillary diameter of $3 \mathrm{~mm}$ (area $=7 \mathrm{~mm} 2$ ). For these values of the pupillary diameter, the values of the spectrum function of hazard and blue light $(B(\lambda)$ - were found. The maximum fell in the spectral radiation band of 435-440 nm.

The theory of the blue light risks and the method of photobiological safety estimation were developed based on the articles by David $\mathrm{H}$. Sliney, Ph.D, the founder of photobiological safety of artificial light sources. For many years, he was the Manager of the Laser/Optical Radiation Program at the US Army Center for Health Promotion and Preventive Medicine. In 2007, he retired. His research interests include: 1) UV effects upon the eye; 2) tissue responses to laser radiation; 3) risks and hazards associated with laser application in medicine. He served as member, advisor and chairman of numerous committees and institutions, which are active in the establishment of safety standards for protection against non-ionizing radiation in particular from lasers and other highintensity optical sources (ANSI, ISO, ACGIH, IEC, WHO, NCRP, and ICNIRP). He co-authored the 1000-page handbook, "Safety with Lasers and Other Optical Sources," Plenum Publishing Corp.,

(C) Kaptsov V.A., Deinego V.N., 2016

Kaptsov Valeriy Alexandrovich - Corresponding Member of Russian Academy of Sciences, Doctor of Medical Sciences, prof., Head of the Occupational Health Department (e-mail: kapcovva39@ mail.ru; tel.: +7 (499) 15-33-628).

Deinego Vitaly Nikolayevich - Project Manager for Lighting LLC "New Energy Technologies", "Technopark Skolkovo», (email: aet@aetechnologies.ru; tel.: +7(495) 280-76-07). 
New York, 1980. He served as President of the American Society for Photobiology, 2008-2009.

David H. Sliney has developed the founding principles of the photobiological lamp safety standards. His methodological pattern were automatically translated to be used on LED-array light. David H. Sliney's students and followers are trying to categorize the risks in order to validate and promote LED light. Today the area of researche and opportunity (limitation) analysis related to LED light includes:

- Governmental agencies including the US Ministry of Energy, the RF Ministry of Energy

- Nonprofit organizations such as Illuminating Engineering Society of North America (IESNA), Alliance for Solid-State Illumination and Technologies (ASSIST), International Dark-Sky Assosiation (IDA) and Nonprofit Partnership of LED Lights and Light Systems Manufacturers;

- Large manufacturers such as PhilipsLumileds, Osram, Cree, Nichia, and Russian manufacturing companies including Optogan, Svetlana Optoelektronika;

Research institutitons, universities, laboratories such as Lighting Research Center at Rensselaer Polytechnic Institute (LRC RPI), National Institute of Standards and Technology (NIST), American National Standard Institute (ANSI), Lodygin Scientific and Research Light Source University, Vavilov Russian Lighting Research Institute.

LED light is in the center of scientific attention: hundres of articles are published and many international conferences take place every year. The finances spent on installing LED light total billions of roubles.

For these reasons, the assessment of photobiological safety is essential for child safety and reduce the threat to the national security.

In determining the excessive blue light dose, it might be helpful to review "The Optical Safety of LED Lighting", a European report that compares the sun light spectrum with the artificial light source spectrums (incandescent, fluorescent and LED lamps) following the requirements of EN 62471. Let us look at the findings from the point of view of hygienic assessment in order to determine the excessive portion of blue light in LED. Figure 1 below shows a spectral pattern of a light-emitting diode that consists of a crystal that emits blue light and is covered with yellow fluorescent dye to obtain white light.

Figure 1 also shows the reference points which require close attention from a hygienist when analyzing the light spectrum from any light source. From this point of view, let us review the sun light spectrum (see Figure 2).

The figure makes it clear that in the color temperature range from $4000 \mathrm{~K}$ to $6500 \mathrm{~K}$, the conditions for the melanopsin cross are observed [3]. In the energy spectrum, the amplitude (A) at 480 $\mathrm{nm}$ shall always be bigger than the amplitude at $460 \mathrm{~nm}$ and $450 \mathrm{~nm}$.

Here, the blue light dose $460 \mathrm{~nm}$ in the sun light spectrum with the color temperature $6500 \mathrm{~K}$ is $40 \%$ bigger that in the sun light with the color temperature $4000 \mathrm{~K}$.

The melanopsin cross effect can be clearly observed from the comparison of the spectrums of thepy incandescent light and LED with the color temperature $3000 \mathrm{~K}$ (see Figure 3).

The excessive portion of blue light in the LED spectrum exceeds the portion of blue light in the incandescent light spectrum by $55 \%$.

With the account for the above, let us compare the sun light at $\mathrm{T}_{\mathrm{K}}=6500 \mathrm{~K}(6500 \mathrm{~K}-$ upper color temperature limit for the retina according to David H. Sliney (below 6000K according to the sanitary norms) with the incandescent light spectrum $\mathrm{T \kappa}=2700 \mathrm{~K}$ and LED spectrum with $\mathrm{T}_{\mathrm{K}}=4200 \mathrm{~K}$ at the light level of 500 lux (see Figure 4). 


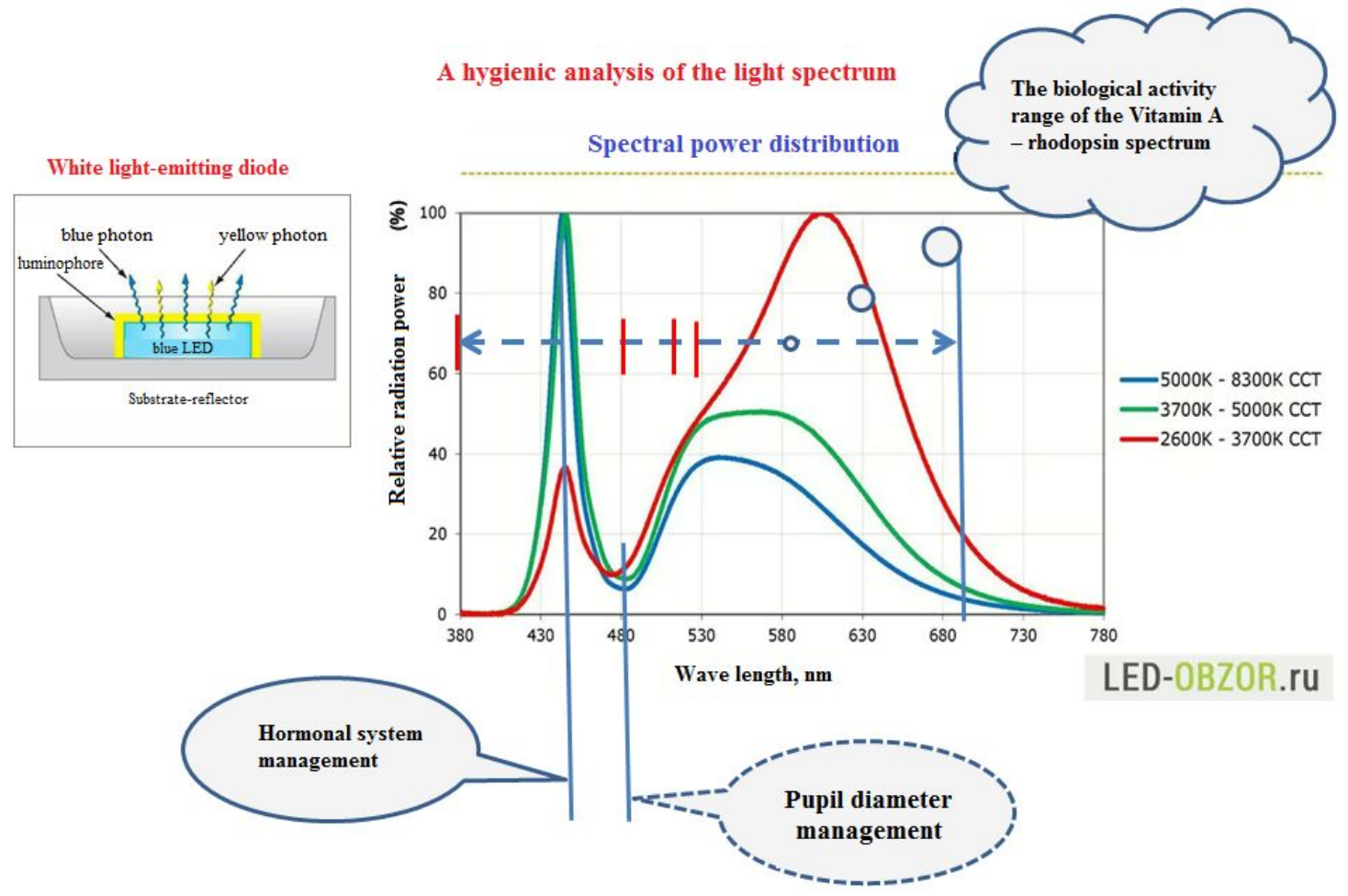

Figure 1. The light spectrum of white light-emitting diode

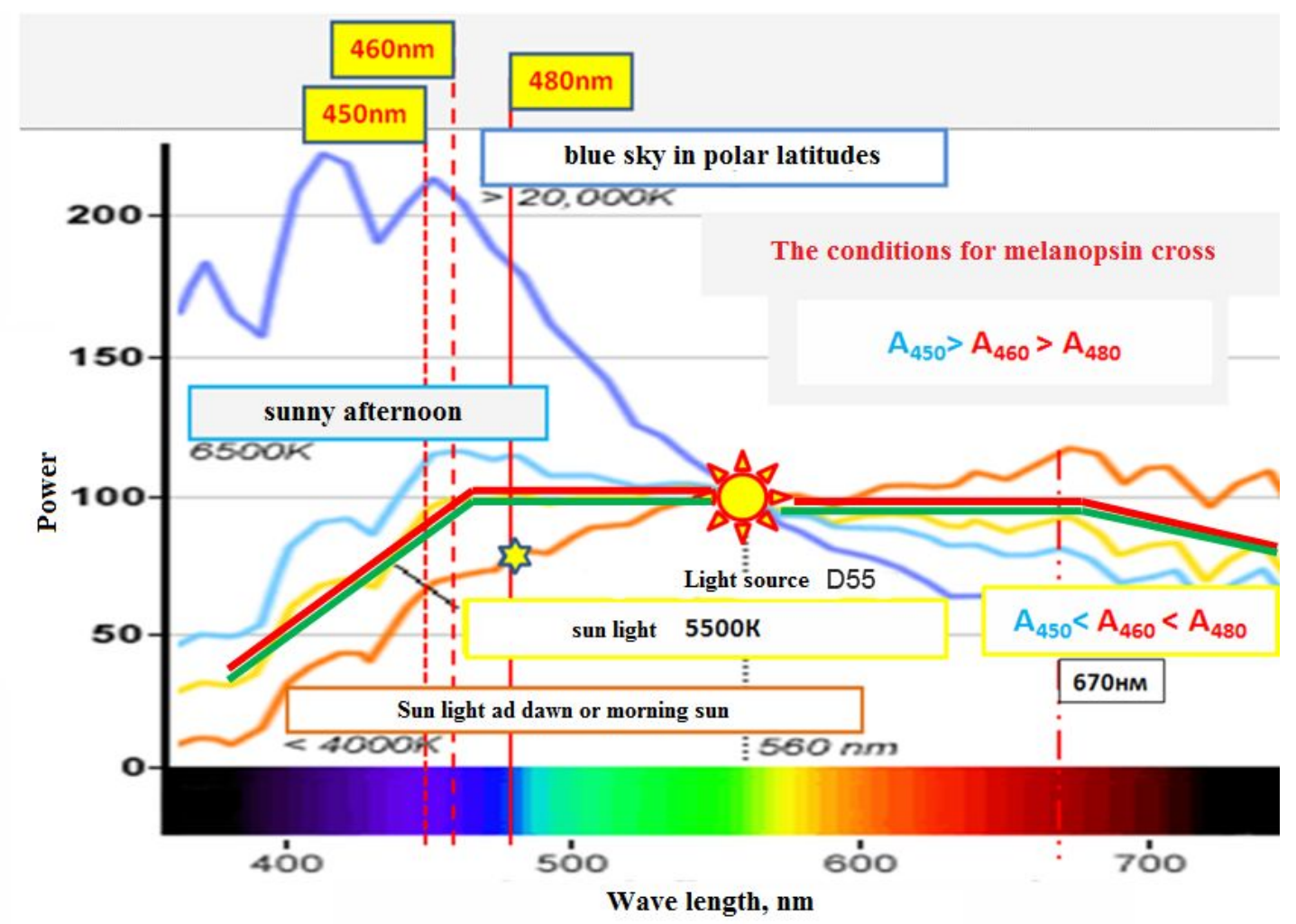

Figure 2. The sun light spectrum at different times of the day 


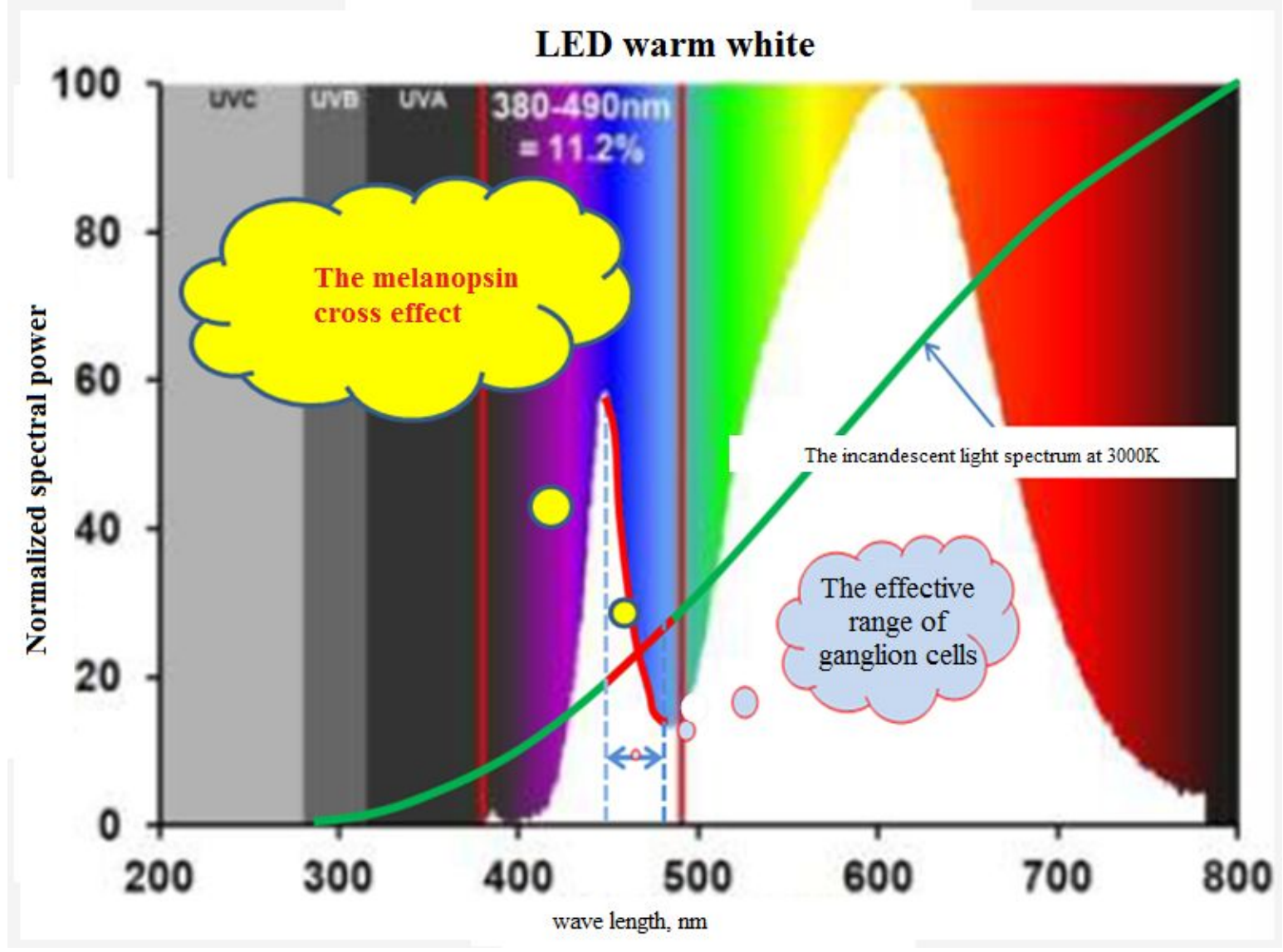

Figure 3. The melanopsin cross effect [3]

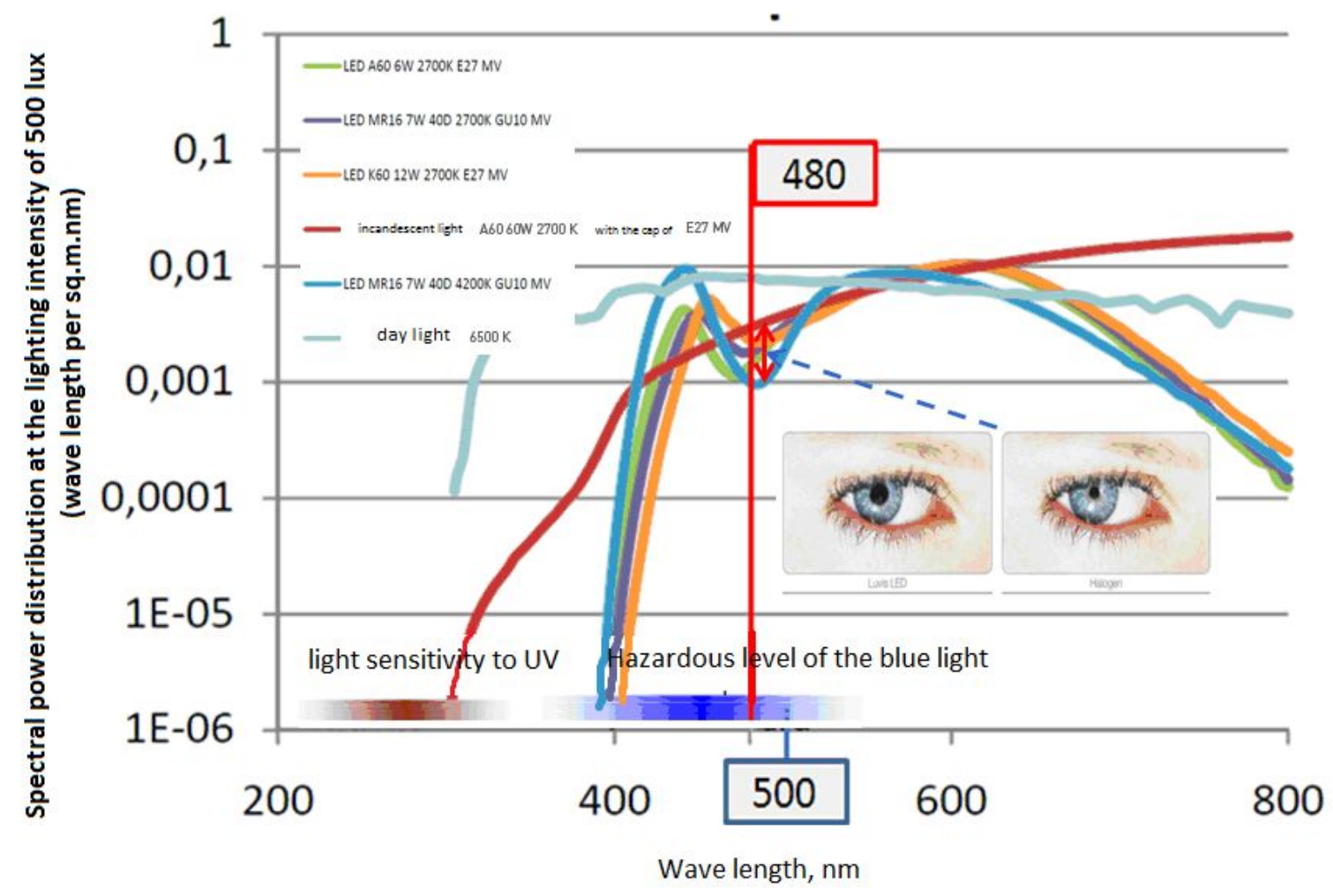


Figure 4. Comparison of the sun light, incandescent light, and LED light spectrums

The figure above shows that

- incandescent light $\left(\mathrm{T}_{\mathrm{K}}=4200 \mathrm{~K}\right)$ has the emission of 460nm higher than sun light $(6500 \mathrm{~K})$;

- in the incandescent light spectrum $\left(\mathrm{T}_{\mathrm{K}}=4200 \mathrm{~K}\right)$, the dip of $480 \mathrm{~nm}$ is 10 times bigger than in the sun light spectrum (6500K);

- in the LED light spectrum $\left(\mathrm{T}_{\mathrm{K}}=4200 \mathrm{~K}\right)$ the dip of $480 \mathrm{~nm}$ is much bigger than in the in the incandescent light spectrum $\left(\mathrm{T}_{\mathrm{K}}=2700 \mathrm{~K}\right)$.

The pupillary diameter in the incandescent light is known to exceed the maximum value of $3 \mathrm{~mm}$ (area $=7 \mathrm{~mm}^{2}$ ) according to GOST R IEC 62471-2013 "Photobiological safety of lamps and lamp systems".

Figure 2 clearly shows that the blue light dose of $460 \mathrm{~nm}$ in the sun light spectrum for the color temperature $4000 \mathrm{~K}$ is significantly lower than the blue light dose of $460 \mathrm{~nm}$ in the sun light spectrum at the color temperature $6500 \mathrm{~K}$.

This means that the blue light dose of $460 \mathrm{~nm}$ in the LED light spectrum with the color temperature $4200 \mathrm{~K}$ will exceed the blue light dose of 460 $\mathrm{nm}$ in the sun light spectrum at the color temperature $4000 \mathrm{~K}$ by $40 \%$ at the same light intensity.

This different composes the excessive blue light dose at the incandescent light in regards to sun light at the same color temperature and the set level of light intensity. This dose must be complemented by the portion of the blue light obtained with the inadequate pupil management in the conditions of LED lighting and from uneven distribution of the luteal pigments (in terms of volume and square) that absorb blue light $460 \mathrm{~nm}$. Total excessive dose of blue light is what accelerates degradation processes and promotes visual deterioration as opposed to sun light under otherwise equal conditions (set light intensity, color temperature, and productivity of the yellow spot) $[1,2,3,4,7,9,10$, $11]$.

The pattern for the retina protection was generated in the sun light. In the sun light spectrum, the pupillary diameter is managed adequately in terms of closing. Consequently, less sun light is received on the retinal cells. The pupillary diameter in adults changes from 1.5 to $8 \mathrm{~mm}$ which controls the intensity of the light received by the retina.
Pupil contraction decreases the area of the light projection of an image which does not exceed the yellow spot area in the central retina. Blue light protection of the retinal cells is provided by the luteal pigment (max absorption of $460 \mathrm{~nm}$ ).

In newborns, the yellow spot region is light yellow, with a blurred outline.

At 3 months, the intensity of yellow light decreases, and the macular reflex starts to develop.

By 12 months, the foveolar reflex is developed, and the center becomes darker.

By 3-5 years, the yellowish tones of the macular region almost blend in with the pink or red color of the central retina.

In children aged 7-10 as well as in adults, the yellow spot region is defined by the avascular central zone of the retina and the eye reflex. The term "yellow spot" resulted from the macroscopic study of the cadaver eyes.

Junction retinal preparations show a small yellow spot. For a long time, the chemical composition of the pigment that colored that retinal area was unknown. Today two pigments: lutein and lutein isomer zeaxanthin - are considered to be yellow spot, or macular pigments. The lutein level is higher in the areas of higher rod concentration, and the level of zeaxanthin is higher in the areas of higher cone concentration. Lutein and zeaxanthin belong to the carotinoids - a group of natural vegetable pigments. Lutein is considered to perform two functions: absorb the hazardous blue light and block/delete the active forms of oxygen created on exposure to light. The lutein and zeaxanthin levels in the macula are uneven in terms of area (the highest concentration is in the center, and a very low concentration is along the edges); moreover, they decrease with age. This means that blue light protection $(460 \mathrm{~nm})$ also deteriorates with age. These pigments are not synthesized in the body so they need to be consumed only with food. This means that the level of blue light protection also depends on the quality of nutrition.

Figure 5 below shows the general pattern of comparison of the projections of the light circle from a halogen lamp (similar to the sun light spectrum) and an incandescent lamp. In the LED light, the flashing area is bigger than in the halogen lamp (HL).

The difference in the flashing areas is used to calculate the additional blue light dose from the 
inadequate pupillary management in the conditions of LED light accounting for the uneven distribution of the pigments that absorb blue light $460 \mathrm{~nm}$ in volume and area.

This qualitative estimation of the excessive blue light dose in the white LED spectrum can serve as a methodological basis for the quantitative estimates in the future. This makes it clear why it is necessary to fill the dip in the region $480 \mathrm{~nm}$ to ensure the reduction of the effect of melanopsin cross. This solution was formalized in an inventor's certificate (LED white light source with a combined remote photoluminescent convector $\mathrm{Pa}$ tent № 2502917 of 30.12.2011). This makes Russia a pioneer in creating LED white light sources with a biologically adequate spectrum. Unfortunately, the RF Ministry of Industry and Trade did not consider this area a priority for research and did not provide funding for the works on general lighting (of schools and hospitals), screens, and car lights.

Inadequate pupillary management in the LED lighting creates the conditions for excessive blue light doses which adversely affect the retinal cells (ganglion cells) and retinal vessels. The above is reflected in the research works by the Institute of Biochemical Physics named after N.M. Emmanuel under the Russian Academy of sciences [5, 6, 12].

The effects related to inadequate pupillary management registered earlier are true for the luminescent and energy-saving lamps (see Figure 6). At that, a higher dose of UV light at $435 \mathrm{~nm}$ is registered ("Optical safety of LED lighting").

The pupil sizes were measured in U.S. school students after the replacement of luminescent lamps $\left(\mathrm{T}_{\mathrm{K}}=3600 \mathrm{~K}\right)$ with luminescent lamps $\left(\mathrm{T}_{\mathrm{K}}=\right.$ $5500 \mathrm{~K})$. The pupil size decreased by $2.3 \mathrm{~mm}^{2}$, and the general psychophysical state of the students improved. Similar results were obtained by the
Research Institute for Hygiene and Children and Teenagers' Health Protection (under the Russian Academy of Medical Sciences) in the course of the experiments which involved the replacement of luminescent lamps with LED lights. In particular, in the luminescent light $\mathrm{T}_{\mathrm{K}}=4000 \mathrm{~K}$, the pupil size equaled $4.9 \mathrm{mmm}$ in diameter.

As the correlated color temperature of the artificial light sources decreased, the pupil size increased. This creates a supposition for an adverse impact of the blue light on the retinal cells and vessels. As the correlated color temperature increased, the pupil size decreased but did not reach the values registered in the day light. Excessive UV dose can foster degradation processes, increase the risks of early visual deterioration as opposed to the sun light under otherwise equal conditions.

A higher dose of blue in the LED spectrum can affect human health and the functioning of the visual analyzer. Which means vision can deteriorate early in life. On a larger scale, this creates a threat to the national security. A certain light spectrum can be used as a weapon of mass impact. This fact was proved in the course of the studies by DARPA conducted in 2008 on SB082-055 U.S. Navy. In the same year, three professors - Stephen Den Baars, Jim Speck, and Sudzi Nakamura jointly with the leading specialists from Philips Lumileds и Intel started a new company Soraa specializing in manufacturing new generation LED lamps (purple LED and RGB-luminophor). They received funding by the U.S. Ministry of Energy and built a pilot plant in Freemont, CA (USA) [8]. Also, Soraa experts received a patent US2015/0062892 A1 of 05.03.2015 «Circadian friendly LED light source» (SORAA, INC, Fremont, CA(US).

According to the patent, circadian friendly LED light sources includes the light sources for: 


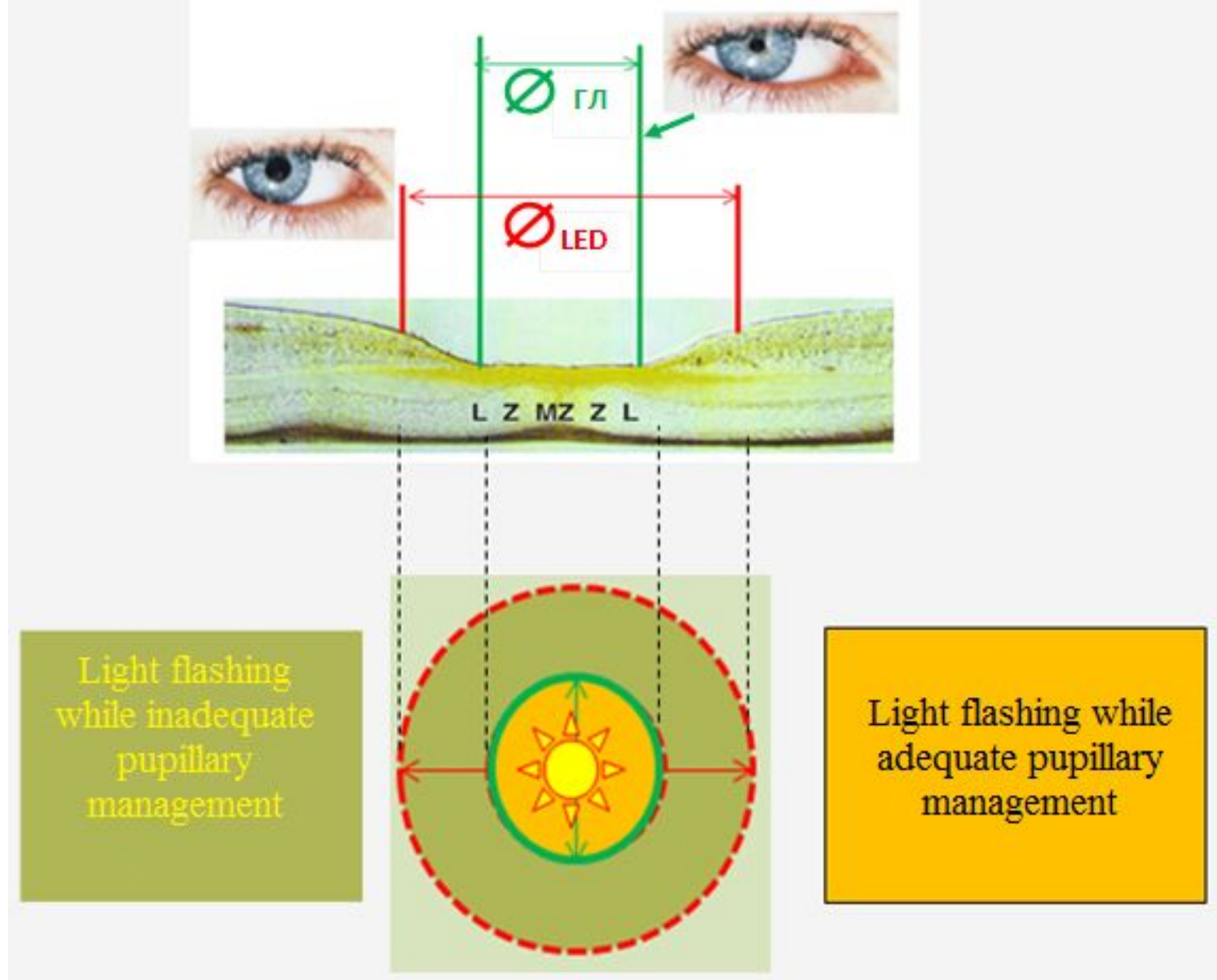

Figure 5. Comparison of the areas of the retina flashing by halogen lamp and incandescent lamp

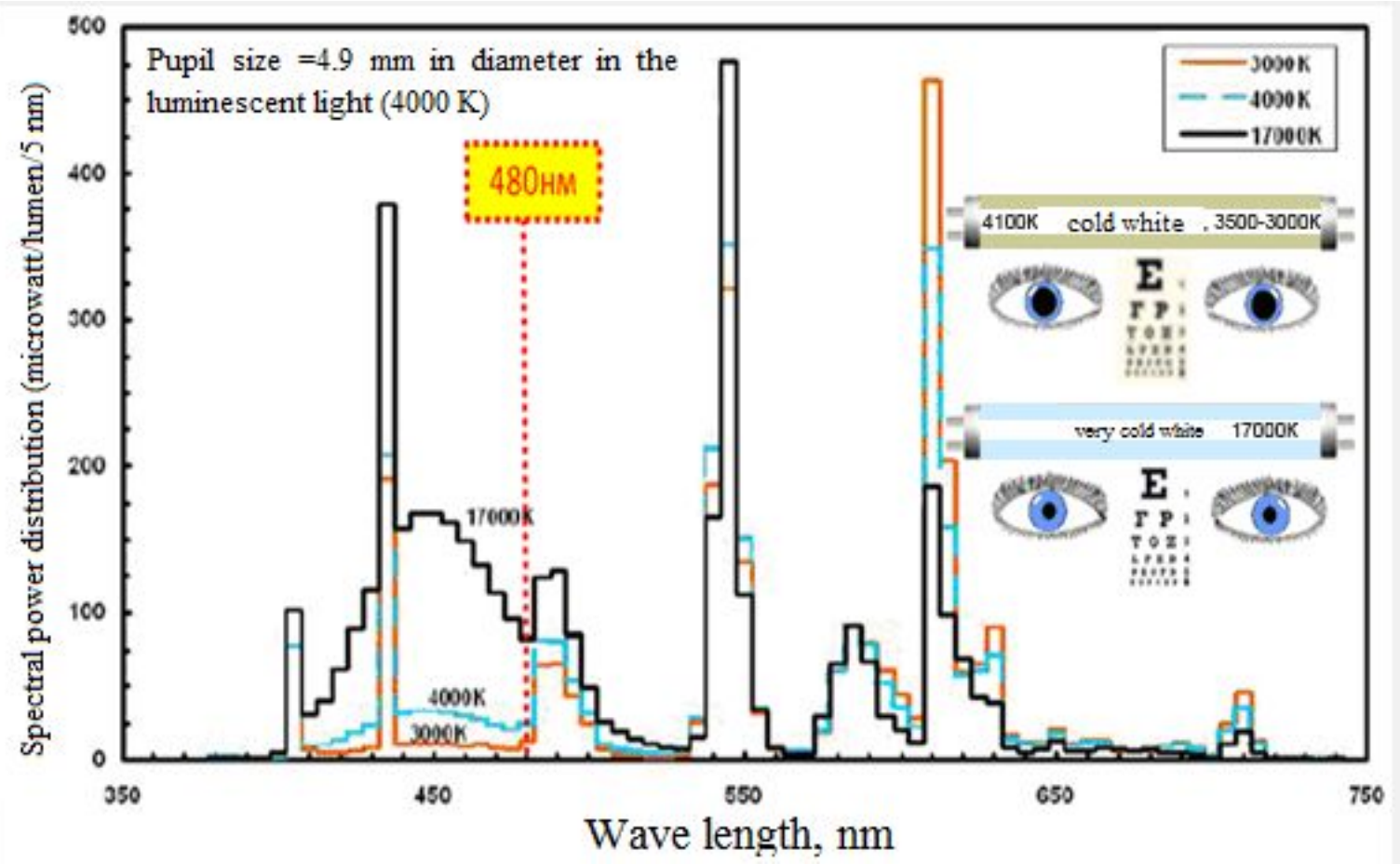


Figure 6. Luminescent lamp spectrums with different values of the correlated color temperature

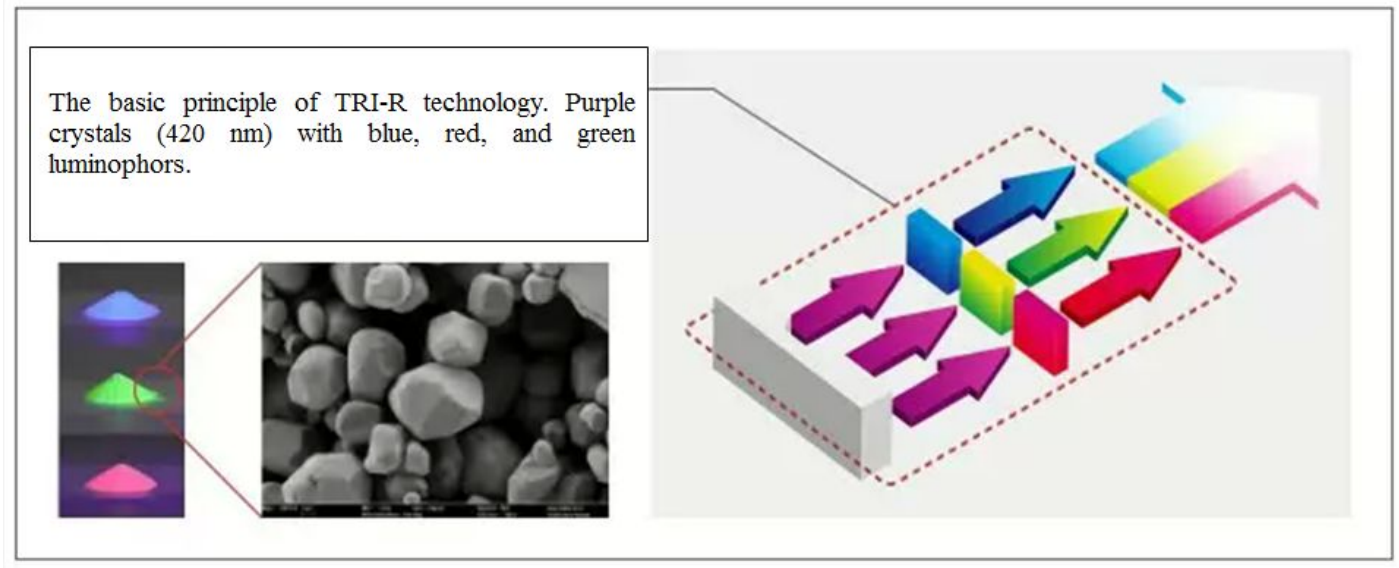

Figure 7. TRI-R Technology
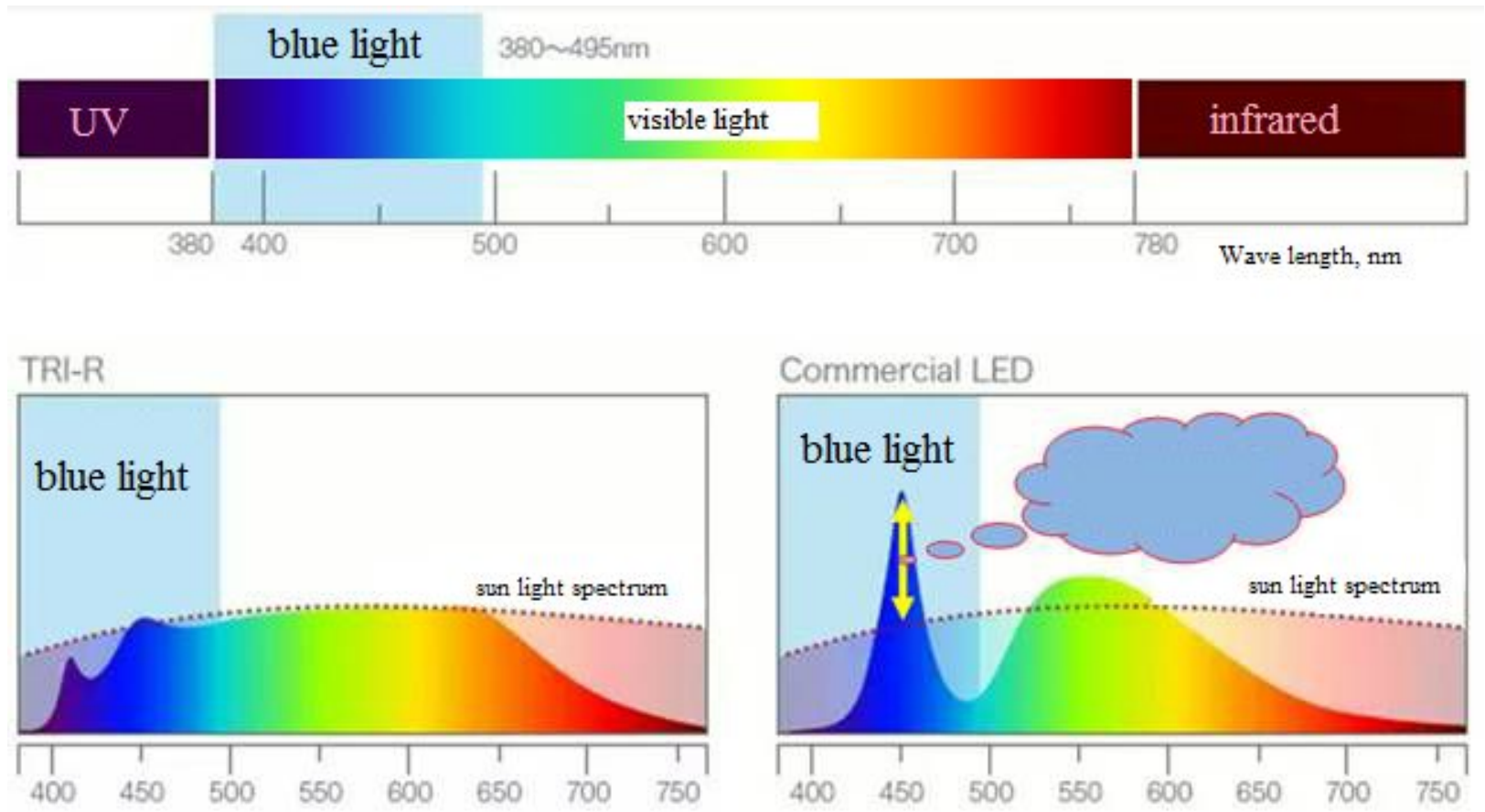

Figure 8. General comparison of the light spectrums

- General lighting; backlight monitors; car lights.

In short, the new ideology by Sudzi Nakamura covers all important areas of application of LED light sources.

In contrast to the conservatism of the RF Ministry of Industry and Trade and innovative center Skolkovo, our proposed concept of semiconductor white light sources with a biologically adequate light is gaining support worldwide. For example, in Japan (Toshiba Material Co., LTD), LEDs were manufactured using TRI-R technology (see Figure 7).

This combination of purple crystals and luminophors allows the synthesis of LEDs with the spectrum close to the spectrum of sun light with different color temperatures, and elimination of shortcomings in the traditional LED spectrum (blue crystal coated with yellow luminophors).

Figure 8 below shows a comparison of the sun light spectrum $(\mathrm{TK}=6500 \mathrm{~K})$ and LED spectrums using TRI-R technology and conventional technology (blue crystal coated with yellow luminophors). 
The figure above shows that the dip of 480 $\mathrm{nm}$ was reduced in the LED white light spectrum using the TRI-R technology, and excessive dose of blue is eliminated.

At this point, we would like to express our support to the international counterparts and hope that that the studies on the impact of light of a certain spectrum on human health will become a priority for the Russian federal government. It will help prevent billion rouble losses in the future.

\section{CONCLUSIONS:}

1. The Sanitary Rules use the norms from international light-regulating documents by translating the European standards into Russian. The standards are developed by the specialists who are promoting their national technology policy (national business) which often does not conform with the Russia's national technology policy. A good example is GOST IEC 62471:2006 Photobiological safety of lamps and lamp systems. In LED light, the pupil size is managed inadequately which places in question the accuracy of photobiological assessments under this GOST.

2. The federal government does not provide funding for the research on the health effects of technology. Hygienists are forced to adapt the norms and requirements to the business-supported technologies.

3. The technical solutions used in the production of lights and PC monitors must ensure visual safety of users by excluding the effect of melanopsin cross which is common in the energy-saving lamps and information display devices.

4. In the white LED light (blue crystal and yellow luminophor) with a spectral dip of $480 \mathrm{~nm}$, the pupil size is managed inadequately.

5. Maternity wards, child facilities, and schools must use hygienically certified lighting with a biologically adequate light spectrum accounting for the specifics of child vision.

\section{References}

1. Deinego V.N., Kaptsov V.A. [Gigiena zrenija pri svetodiodnom osveshhenii. Sovremennye nauchnye predstavlenija]. Visual hygiene in LED lighting. Modern scientific imaginations. Gigiena i sanitarija, 2014, Vol. 93, no. 5, pp.54-58. (in Russian).

2. Deinego V.N., Kaptsov V.A. Gigiena truda vrachej-hirurgov. Sovremennye problemy: nauchnyj obzor [Occupational health of surgeons. Modern problems (Scientific review)]. Profilakticheskaja $i$ klinicheskaja medicina, 2014, no. 1 (50), pp. 26-29. (in Russian).

3. Kaptsov V.A., Deinego V.N. Svet jenergosberegajushhih i svetodiodnyh lamp i zdorov'e cheloveka [Energy saving and LED lamp litghting and human health]. Gigiena i sanitarija, 2013, no. 6, pp. 81-84. (in Russian).

4. Deinego V.N., Kaptsov V.A., Soroka A.I. Vlijanie sveta i fizicheskih polej na risk disgarmonizacii sinteza melatonina $\mathrm{v}$ shishkovidnoj zheleze [Influence of light and physical fields on risk of disharmonization of melatonin synthesis in the pineal gland]. Analiz riska zdorov'ju, 2014, no. 2, pp.30-41. (in Russian).

5. Zak P.P., Zykova A.V., Trofimova N.N. [et al.]. Jeksperimental'naja model' dlja issledovanija mehanizmov vozrastnyh i degenerativnyh izmenenij v setchatke glaza cheloveka (japonskij perepel C. japonica) [Experimental model of studying mechanisms of age-related and degenerative changes in the retina of the human eye (Japanese quail C. japonica)]DAN, 2010, Vol. 434, no. 2, pp. 272-274. (in Russian).

6. Zak P.P., Zykova A.V., Trofimova N.N., Ostrovskij M.A. Japonskij perepel Coturnix japonica kak model' uskorennogo starenija setchatki glaza cheloveka. Soobshhenie 1. Zavisimost' nakoplenija lipofuscina v kletkah retinal'nogo pigmentnogo jepitelija ot urovnja soderzhanija retinal'nyh oksikarotinoidov [Japanese quail Coturnix japonica as a model of accelerated aging of the retina of the human eye. Report 1 . The dependence of the accumulation of lipofuscin in the cells of the retinal pigment epithelium on the level of retinal oxycarotinoids]. Oftal'mohirurgija, 2013, no. 1, pp. 9-12. (in Russian).

7. Kaptsov V.A. Deontologicheskie voprosy zheleznodorozhnoj gigieny [Deontological issues in railway hygiene]. Gigiena i sanitarija, 2015, Vol. 94, no. 3, pp. 40-43. (in Russian).

8. Kaptsov V.A., Deinego V.N. Izmenenija $\mathrm{v}$ koncepcii postroenija svetodiodov dlja osveshhenija $\mathrm{s}$ uchetom zdorov'ja cheloveka [Changes of the concept of building LED lighting, taking into account human health]. Jelektronnyj zhurnal «JeNERGOSOVET», 2015, no. 4 (41), pp. 40-44. (in Russian).

9. Kaptsov V.A., Deinego V.N. Immunnaja sistema i iskusstvennaja svetovaja sreda [Immune system and artificial light environment]. Allergologija i immunologija, 2015, Vol. 16, no. 3, pp. 253-258. (in Russian).

10. Kaptsov V.A., Deinego V.N. Riski vlijanija sveta svetodiodnyh panelej na sostojanie zdorov'ja operatora [Influence risks of the LED panel light on an operator's health]. Analiz riska zdorov'ju, 2014, no. 4, pp.37-46. (in Russian).

11. Kaptsov V. A., Sosunov N.N., Shishchenko I.I., Viktorov V.S., Tulushev V.N., Deinego V.N., Bukhareva E.A., Murashova M.A., Shishchenko A.A. Funkcional'noe sostojanie zritel'nogo analizatora pri ispol'zovanii 
tradicionnyh i svetodiodnyh istochnikov sveta [Functional state of the visual analyzer in the conditions of the use of traditional and LED light sources]. Gigiena i sanitarija, 2014, Vol. 93, no. 4, pp.120-123. (in Russian).

12. Sigaeva A.O., Seriozhnikova N.B., Pogodina L.S., Trofimova N.N., Dadasheva O.A., Gur'eva T.S., Zak P.P. Izmenenija sosudistoj obolochki glaza raznovozrastnyh grupp japonskogo perepela Coturnix Japonica v zavisimosti ot spektral'nogo sostava osveshhenija [Changes of the choroid of different age groups of Japanese quails Coturnix japonica depending on the spectrum composition of illumination]. Sensornye sistemy, 2015, Vol. 29, no. 4, pp.354-361. (in Russian). 